\title{
Sciendo
}

Administration, vol. 66, no. 3 (2018), pp. 1-4

doi: 10.2478/admin-2018-0024

\section{Contemporary governance in Northern Ireland: Introduction}

\author{
Markus Ketola \\ School of Applied Social and Policy Studies, Ulster University, \\ Northern Ireland \\ Karl O'Connor \\ School of Applied Social and Policy Studies, Ulster University, \\ Northern Ireland
}

Public administration in the devolved regions of the UK has always been a complex, difficult and often haphazard process, but nowhere have these characteristics been quite as pronounced as in Northern Ireland. The contributions presented here are not intended to present a comprehensive overview of governance in Northern Ireland but rather to pick up on a select number of current key issues that characterise both the operational environment of the public sector in Northern Ireland and the unique and often challenging contemporary policy context.

The issue begins with an article by Colin Knox \& Seamus McCrory examining how local authorities can play a role in developing policies that respond to the collective citizen need rather than focusing on the traditional community relations model of service delivery. Nat O'Connor too considers service delivery, suggesting that we need to include 'public value' in any measurement of policy success. Michelle Rouse in turn examines the gender dimension of the policymaking 
process within the Northern Ireland civil service and its impact on post-conflict policymaking. The impact of Brexit and the crisis in health and social care have consistently appeared at the top of the current governance agenda. Gordon Marnoch and Alexandra Chapman reflect on the governance challenges posed by these two impending realities.

In order to thematise the contribution of this special issue, we make reference to three concepts. Firstly, we return to the much cited, 'wicked' policy problems (Rittel \& Webber, 1973). They are complex, ambiguous and long-lasting, and there are various perspectives to them. There are no solutions that are undisputable, nor can they be solved by focusing on one perspective or approach at a time, but rather the solutions are usually multidimensional and multidisciplinary. The challenges are also complex and systemic by nature (see Holland, 1995), which means that various dimensions of activity and diverse actors are needed for a sustainable change. Addressing such policy challenges in a complex and volatile environment requires a collaborative approach that incorporates the views and interests of a wide range of stakeholders (e.g. Loorbach, 2007). The article by Knox \& McCrory outlines some of the key contours of the wicked problems of sectarianism, divided communities and social deprivation, which in themselves are interrelated as well as interdepartmental in nature, requiring a response at all levels of government. Their contribution is particularly timely given renewed calls for local government to step in to fill the void left by an absent Assembly.

Secondly, we wish to take a moment to reflect on Robert Merton's seminal study from the 1930s, 'The Unanticipated Consequences of Purposive Social Action'. Merton (1936, p. 899) persuasively argues that for any social action, there will always be a range of consequences, 'any one of which may follow the act in any given case'. His focus was on 'social prediction, control and planning' (p. 904), which broadly aligns with many of the roles of the present day public administration. He suggests that social action implies a degree of irrationality of human action, because the only certain thing in relation to the outcomes of social action, such as the implementation of a new policy, is uncertainty. In other words, the complexity of the social interactions that follows any policy decision is always such that its consequences are not restricted to the specific area in which they were initially intended to centre' (p. 903). Merton's point is ultimately that the confluence of multiple factors in any policy process makes it impossible to anticipate the outcomes of that process. The articles 
presented in this issue articulate the policy process within five topical areas of social policy so that we may better understand the consequences of policy choices within these policy arenas.

Knox \& McCrory note the dearth of effective means to measure policy impact beyond the crude religious head count of participants in community-level programmes, generating more policy uncertainty for the policymaker, on top of the unpredictable nature of the peace process. O'Connor too recognises the challenge of capturing, or measuring, the outcomes of the actions of public administration in an accurate way, and proposes a way to rethink and rearticulate this through the framework of public value. Marnoch and Chapman shed light on some of the most complex policy problems faced by the Northern Irish administration today: health and social care, and the implications of Brexit.

Thirdly, the contributions engage in what might be termed a 'post New Public Management (NPM)' turn in the study of public administration. As Reitner \& Klenk (2018) outline in their systematic literature review on the meanings of 'post-NPM' academic literature, a now well-established field within the discipline, such approaches have proved an 'ideational weapon' with which to problematise and critically engage with the NPM model. The articles in this special issue resonate with a post-NPM approach to thinking about contemporary problems and challenges in public administration. Some of the key characteristics of a post-NPM approach can be summarised as a (re-)centralisation of governance through initiatives such as improved inter-agency coordination and development of 'one-stop shops' for a range of services; the repoliticisation of administration and delivery of public services; and a focus on new mechanisms for achieving legitimacy and accountability for a public sector that moves away from a marketised approach of treating citizens as customers with choices and communicating a clearer sense of public values (Reiter \& Klenk, 2018).

Knox \& McCrory highlight the importance of interdepartmental and cross-sectoral work in effectively addressing the wicked legacy problems of the conflict. O'Connor, focusing explicitly on the questions of public value, tackles head on the questions of legitimacy and accountability raised in the post-NPM literature. Rouse looks at the development of the Northern Ireland civil service and considers how its institutional norms influence its policy responses from a gender perspective. Similarly, in the Forum section, the complex policy challenges in adult social care highlighted by Chapman will 
require a more holistic approach if they are to be effectively addressed. Marnoch, in taking the pulse of the impact of Brexit on health policy, compels the reader to think about the ways in which these policy processes have been not only depoliticised but also centralised.

Governing Northern Ireland presents numerous unique challenges. In this issue we highlight some of the challenges currently facing the region and propose some policy options for policymakers to consider.

\section{References}

Holland, J. H. (1995). Hidden order: How adaptation builds complexity. Jackson, MS: Perseus Books.

Loorbach, D. (2007). Transition management: New mode of governance for sustainable development. Utrecht: International Books.

Merton, R. (1936). The unanticipated consequences of purposive social action. American Sociological Review, 1 (6), 894-904.

Reitner, R., \& Klenk, T. (2018). The manifold meanings of 'post-New Public Management' - a systematic literature review. International Review of Administrative Sciences. Advance online publication. doi: 10.1177/0020852318759736

Rittel, H. W. J., \& Webber, M. W. (1973). Dilemmas in a general theory of planning. Policy Sciences, 4 (2), 155-69. 